\title{
PROSES INFORMASI PADA PERINGATAN KESEHATAN DALAM KEMASAN ROKOK
}

\author{
Yoma Bagus Pamungkas \\ Mahasiswa Magister Ilmu Komunikasi FISIP UNDIP \\ Email:yomabagus@yahoo.co.id
}

\begin{abstract}
Indonesia has high number of tobacco consumers. Therefore, government through the Ministry of Health decreed regulation of health warning relating to itineach cigarette package. The regulation includes the Pictorial Health Warning (PHW) and Health Information Message (HIM) which aims to reduce interest ontobacco. The purpose of this articleis to examine of how the regulation influence smokers behaviour on consuming tobacco. This study apply some concepts including attention and message processing, elaborative processing, cognitive response theory, fear appeals and fear arousal. The result shows that on health warning sindicate that there is coherence between external stimuli (fearappeal) which described by Elaboration Likelihood Model (ELM) with cognitive meaning by smokers, so that can evoke fear in their self to quite smoking.
\end{abstract}

Keywords: tobacco, Elaborative Processing, Cognitive Respon Theory, Fear Appeals and Fear Arousal

\section{PENDAHULUAN}

Penggunaan tembakau untuk rokok di dunia terus meningkat dari waktu ke waktu, sehingga hal tersebut melatarbelakangi WHO (World Health Organization) dengan negaranegara anggotanya menyepakati penerapan kebijakan terhadap kontrol akan tembakau sejak Februari 2003. Penerapan kebijakan tersebut tertuang dalam FCTC (Framework Convention on Tobacco Control). FCTC merupakan bentuk dari traktat internasional yang isinya menegaskan pentingnya strategi pengendalian tembakau serta merupakan sebuah bentuk komitmen dari solidaritas global dalam menghadapi epidemi tembakau di dunia.

Menurut WHO, jumlah perokok di seluruh dunia mencapai 1,2 miliar orang dan 800 juta orang diantaranya berada di negara berkembang
(Infodatin, Pusat Data dan Informasi Kementerian Kesehatan RI, Mei 2014), kemudian WHO juga menyatakan bahwa kematian akibat merokok di seluruh dunia mencapai 6 juta orang per-tahun (www.republika.co.id/berita/gaya-hidup/infosehat/15/09/11/nuh20i359-who-rokokpembunuh -enam-juta-orang-per-tahun).

Selanjutnya The ASEAN Tobacco Control Atlas Second Edition, menjelaskan lebih rinci terkait dengan presentase penduduk dunia yang mengkonsumsi tembakau. Didapatkan data sebanyak 56\% penduduk Asia Pasific, 24\% penduduk Eropa, $11 \%$ penduduk Amerika, dan 9\% penduduk Timur Tengah serta Afrika yang mengkonsumsi tembakau. Sedangkan khusus jumlah perokok di wilayah ASEAN adalah 121.156.804 jiwa dari jumlah populasi penduduk 
ASEAN sebesar 625.096.300 jiwa. Dari jumlah tersebut, ASEAN sendiri menyumbang $10 \%$ dari total jumlah perokok di dunia. Jumlah tersebut tersebar di negara anggota ASEAN dengan presentase Indonesia sebesar 50,68\%, Filipina 14,28\%, Vietnam 12,63\%, Myanmar 7,32\%, Thailand 8,89\%, Malaysia 3,91\%, Kamboja $1,22 \%$, Laos $0,72 \%$, Singapura $0,29 \%$, dan Brunei 0,06\% (TATCA Second Edition, September 2014). Akibatnya dari mengkonsumsi tembakau tersebut, lebih dari 1,3 juta orang dalam setiap tahunnya meninggal di Asia Tenggara (www.republika.co.id/berita/gaya-hidup/infosehat/15/09/11/nuh1xx359-who-rokokpenyebab-utama-kematian).

Indonesia merupakan negara yang memiliki jumlah konsumsi tembakau terbesar ketiga di dunia setelah China dan India (Infodatin, Pusat Data dan Informasi Kementerian Kesehatan RI, Mei 2014). Berdasarkan penulisan oleh The Institute for Health Metrics and Evaluation yang dilakukan pada tahun 1980-2012 menyebutkan bahwa jumlah perokok di Indonesia dalam 30 tahun terakhir sebesar 57\% (Ng, 2014). Presentase jumlah perokok tersebut meningkat pada tahun 2013 sebesar 67\% (GHCC, 2014). Lebih lanjut menurut data Riset Kesehatan Dasar (Riskesdas) oleh Kementerian Kesehatan Tahun 2013, bahwa jumlah perokok tersebut terbagi menjadi perokok laki-laki $64,9 \%$ dan sisanya adalah perokok perempuan sebesar 2,1\% (RISKESDA 2013). Kemudian tak terkecuali jumlah perokok usia muda. Berdasarkan data terakhir Riset Kesehatan Dasar 2013 perokok aktifmulai dari usia 10 tahun ke atas berjumlah 58.750 .592 orang, yang mana jumlah tersebut terdiri dari 56.860 .457 perokok laki-laki dan 1.890.135 perokok perempuan (www.health. kompas. com/read/2015/06/03/110000223/ Jumlah.Perokok. Indonesia.10.Kali. Lipat. Penduduk. Singapura). Sejalan dengan hal diatas, angka kematian akibat tembakau juga sangat tinggi. Menurut hasil penulisan Badan Litbang Kemenkes tahun 2010 menunjukkan bahwa kematian akibat penyakit yang terkait dengan tembakau terjadi pada 190.260 orang atau sekitar $12,7 \%$ dari seluruh kematian di tahun yang sama (www.depkes.go.id/article/view/15060900001/ rokok-illegal-merugikan-bangsa-dannegara.html).

Oleh karena itu sebagai langkah untuk menekan angka jumlah perokok dan kematian akibat merokok, pemerintah mengeluarkan kebijakan kontrol terhadap tembakau yang tertuang dalam Peraturan Pemerintah Republik Indonesia Nomor 109 Tahun 2012 tentang pengamanan bahan yang mengandung zat adiktif berupa produk tembakau bagi kesehatan, yang kemudian diperjelas dengan Peraturan Menteri Kesehatan Republik Indonesia Nomor 28 Tahun 2013 tentang pencantuman peringatan kesehatan dan informasi kesehatan pada kemasan produk tembakau.

Kebijakan kontrol peringatan kesehatan yang pertama berupa Pictorial Health Warning (PHW). Pictorial Health Warning (Peringatan Kesehatan Bergambar) adalah pernyataan, sisipan informasi produk, atau iklan yang berupa gambar yang memperingatkan konsumen bahwa produk tersebut memiliki dampak yang merugikan pada kesehatan mereka atau kesehatan orang lain (11th World Conference on Tobacco OR Health. 2000. Promoting a Future Without Tobacco. ${ }^{-}$Tobacco Warning Labels and Packaging. August 6-11", dalam Tallah, 2013: 17). Selanjutnya Hammond juga mengatakan bahwasannya PHW adalah suatu cara untuk menginformasikan kepada masyarakat melalui pernyataan atau sisipan pada kemasan produk tembakau (rokok) yang berisi informasi kesehatan dan informasi tentang bahaya serta resiko penyakit yang disebabkan oleh produk tembakau guna mempengaruhi masyarakat untuk berhenti merokok (Hammond, 2011 : 327-337). Kedua tentang informasi kesehatan atau dapat disebut Health Information Message (HIM) yang berupa: a) tentang kandungan kadar nikotin dan tar, (b) tentang pernyataan "dilarang menjual 
atau memberi kepada anak berusia di bawah 18 tahun dan perempuan hamil", dan (c) tentang kode produksi, tanggal, bulan, dan tahun produksi, serta nama dan alamat produsen (Permenkes RI No. 28 Tahun 2013).

Selanjutnya pencantuman peringatan kesehatan dan informasi kesehatan pada kemasan produk tembakau tersebut dimulai pada tanggal 24 Juni 2014, dimana sebelumnya aturan pelaksanaan tersebut telah memberikan waktu selama 18 bulan (terhitung sejak Desember 2012) bagi para perusahaan industri rokok untuk mulai memuat peringatan kesehatan dan informasi kesehatan tersebut.

Kemudian jika ditinjau dari persepsi para perokok, dalam survey yang dilakukan oleh Fakultas Kesehatan Masyarakat Universitas Indonesia (FKM UI) - SEACTA 2014, menemukan bahwa PHW belum benar-benar mampu menyadarkan para perokok akan bahaya rokok (www.indonesiatobacco.com/2014/09/ mencegah-perokok-pemula-dengan-phw.html.) Hal tersebut bertolak belakang dengan upaya pemerintah melalui kebijakan Permenkes Nomor 28 Tahun 2013 tentang "Pencantuman Peringatan Kesehatan dan Informasi Kesehatan pada Kemasan Produk Tembakau" yang mengharapkan dapat menekan dan mengurangi jumlah perokok. Namun kenyataannya walaupun sudah distimuli dengan aturan tersebut jumlah perokok di Indonesia masih tinggi. Berangkat dari hal itulah penulis menyajikan bagaimana proses informasi pada peringatan kesehatan yang terdapat dalam kemasan rokok.

\section{PEMBAHASAN}

Berdasarkan jumlah perokok di Indonesia yang masih tinggi, pemerintah memberikan kebijakan berupa pencantuman Peringatan Kesehatan dan Informasi Kesehatan atau dapat disebut Pictorial Health Warning (PHW) dan Health Information Message (HIM) di setiap kemasan rokok.

\section{Pictorial Health Warning dan Health Information Message}

Pictorial Health Warning (PHW) berisi tentang pesan peringatan kesehatan akan ancaman konsekuensi kesehatan akibat dari merokok. Peringatan kesehatan tersebut bertujuan untuk menarik perhatian, menanamkan / memunculkan rasa takut akan konsekuensi negatif, dan memotivasi si penerima pesan supaya merubah atau menghindari perilaku yang beresiko. Salah satu strategi yang digunakan dalam menyebarluaskan pesan tersebut adalah dengan menggunakan gambar grafis pada pesan peringatan kesehatan tersebut.

Gambar grafis dapat didefinisikan sebagai visual yang "ditandai dengan deskripsi manusia hidup atau realita yang jelas" dan "jelas atau jelas ditampilkan atau dijelaskan" (Merriam-Webster Online Dictionary, n.d.). Senada dengan hal tersebut Sara E. Dieterich (2012) menyatakan bahwa selama label pesan atau peringatan tersebut berisi tentang penggambaran yang jelas akan suatu konsekuensi negatif, maka isi pesan tersebut dapat disebut atau diklasifikasikan sebagai grafis. Jadi PHW disini merupakan sebuah grafis, selanjutnya PHW atau gambar grafis dalam pesan peringatan kesehatan ini berupa gambar kanker mulut, kanker paru-paru, kanker tenggorokan, efek asap rokok terhadap anak kecil, dan gambar tengkorak yang terkait dengan kematian akibat merokok.

Gambar grafis pada pesan peringatan kesehatan mungkin efektif untuk perubahan sikap dan perilaku seorang perokok. Hal ini sesuai dalam sebuah review tentang bujukan dan seruan rasa takut oleh Witte dan Allen (2000), mereka menyimpulkan bahwa prediktor terkuat dari efektivitas pesan adalah keparahan penggambaran konsekuensi, dan tingkat keparahan berspekulasi untuk memasukkan gambar hidup/nyata atau mengerikan. Hal ini juga diperkuat dengan temuan Kees, Burton, Andrews, dan Kozup (2010), mereka 
menemukan bahwa peringatan bergambar grafis yang menggambarkan penyakit mulut pada kemasan rokok membangkitkan rasa takut dan memperkuat niat untuk berhenti. Beberapa bukti atau temuan ini menunjukkan bahwa isi dari gambar (grafis) mungkin merupakan sebuah komponen yang efektif dari suatu kampanye pencegahan akan perilaku merokok.

Namun hal berbeda didapatkan jika pesan peringatan kesehatan hanya dalam bentuk teks atau Health Information Message (HIM), Robinson dan Killen (1997) menemukan bahwasannya label peringatan yang hanya berupa teks tidak efektif di antara perokok remaja, mereka tidak melihat, membaca, atau mengingat label peringatan tersebut. Jadi pesan peringatan kesehatan yang berupa gambar grafis (PHW) mungkin merupakan salah satu cara yang efektif untuk mencegah perilaku merokok.

\section{Attention and Message Processing (Proses Pengolahan Pesan dan Perhatian)}

Menurut beberapa pernyataan diatas menunjukkan bahwa gambar grafis dapat berpengaruh terhadap audien. Dimana alokasi dari perhatian dan pengolahan pesan adalah komponen terpenting dari respon individu untuk pesan peringatan kesehatan tersebut. Seperti dalam perspektif pemrosesan informasi oleh McGuire (1989), seseorang harus memperhatikan peringatan tersebut untuk memahami pesan persuasif atau label peringatan. Maksudnya adalah tanpa perhatian tersebut dan pemahaman yang komprehensif, sikap dan perubahan perilaku tidak dapat terjadi. Sebaliknya mengenai deskripsi yang hanya berupa teks tentang konsekuensi kesehatan dianggap tidak menarik perhatian atau tidak dapat mempengaruhi perilaku (Argo \& Main, 2004).

Oleh karena itu gambar grafis sering digunakan atau dipakai pada kemasan rokok untuk meningkatkan perhatian si penerima pesan terhadap pesan yang ada pada peringatan kesehatan tersebut. Sehingga kemasan rokok yang baru dan terdapat PHW dinilai lebih dapat merebut perhatian perokok atau calon perokok daripada kemasan yang lama yang hanya berisi peringatan berupa teks saja.

\section{Elaborative Processing (Proses Elaboratif)}

Lebih lanjut dalam pemprosesan pesan, gambar grafis pada peringatan kesehatan pada kemasan rokok mungkin hanya memiliki efek sekilas atau sepintas pada individu pada saat mereka pertama kali melihat / mengetahuinya. Namun setelah itu kognitif mereka akan memproses peringatan tersebut dengan tingkat elaborasi yang berbeda. Berdasarkan Model / Teori Kemungkinan Elaborasi Persuasif(ELM; Petty \& Cacioppo, 1986), proses elaborasi yang tinggi pada suatu pesan terjadi pada saat sebuah pesan harus benar-benar dipertimbangkan. Pertimbangan yang disengaja ini disebut sebagai rute utama (jalur sentral) untuk perubahan sikap dan persuasi. Sementara itu, proses elaborasi yang rendah ditandai dengan adanya ciri pesan yang tidak terkait dengan argumen pesan (misalnya, daya tarik sebuah sumber atau suatu keahlian). Proses ini dikenal dengan sebutan rute periperal (tidak langsung mengena pada pokok/inti pesan) untuk perubahan sikap dan persuasi.

Sikap yang terbentukmelalui rute pusat telah terbukti lebih elastis secara temporer, lebih prediktif terhadap perilaku, dan lebih tahan/kuat untuk melawan persuasi (van Schie, Martijn, \& van der Pligt, 1994). Gambar grafis dinilai dapat mempengaruhi sejauhmana peringatan tersebut diproses, peringatan kesehatan dalam bentuk gambar grafis ini dapat meningkatkan proses elaborasi dengan rute / jalur utama/ sentral dan mungkin proses ini dinilai akan lebih efektif untuk perubahan sikap dan niat berhenti merokok daripada peringatan kesehatan yang hanya berupa teks.

Hal ini sesuai dengan temuan Hammond, Fong, McDonald and Brown (2003) pada 
penelitiannya di Kanada, yang menyatakan bahwa ada sebuah korelasi positif yang kuat antara jumlah pengolahan label peringatan rokok grafis di kalangan Kanadian dengan keinginan para perokok untuk berhenti merokok.

Di sisi lain, peringatan kesehatan bergambar juga dapat berfungsi sebagai alat atau cara untuk pengolahan secara periferal (tidak secara langsung). Rute atau jalur periferal terhadap suatu persuasi dapat terjadi apabila si penerima pesan memiliki motivasi yang rendah untuk memproses argumen pesan yang terdapat pada peringatan kesehatan tersebut, dan mungkin dengan memberikan daya tarik pada peringatan kesehatan tersebut supaya dapat mempengaruhi persuasi si penerima pesan (Petty \& Cacioppo, 1986). Hal ini berarti, proses pengolahan secara periferal dapat mempengaruhi efektivitas peringatan kesehatan terhadap perubahan sikap dan niat si penerima pesan yang memiliki motivasi rendah terhadap pesan dalam peringatan kesehatan tersebut. Para perokok, terutama mereka yang jarang merokok (merokok sesekali) atau baru mulai merokok, akan / dapat termotivasi untuk mempertimbangkan isi pesan pada peringatan kesehatan apabila mereka tidak merasa bahwa peringatan kesehatan tersebut relevan dengan keadaan mereka. Sebagai rute periferal terhadap sebuah persuasi dapat menjadi sebuah karakteristik pesan seperti ketertarikan, isi grafis dari peringatan kesehatan juga dapat berfungsi sebagai ciri dari suatu proses elaborasi secara periferal.

\section{Cognitive Respon Theory (Teori Respon Kognitif)}

Selanjutnya PHW dan HIM ditinjau dari sudut pandang Teori Respon Kognitif(Cognitive Respon Theory). Teori Respon Kognitif adalah sebuah teori untuk mengenali proses kognisi pada iklan melalui tahap pengolahan informasi (tataran kognisi), perubahan sikap terhadap merek (tataran afeksi) yang pada akhirnya menuju pada keputusan pembelian (tataran konasi) (Belch \& Belch, 2001). Pencetus Teori Respon Kognitifadalah Anthony G. Gerald yang berasal dari penulisannya yang dimulai pada tahun 1930 tentang perubahan sikap. Teori Respon Kognitif berusaha memahami hubungan antara respon awal terhadap komunikasi dengan perubahan sikap yang dihasilkan. Teori ini mengatakan bahwa respon kognitif mempengaruhi sikap akhir, sehingga dapat mempengaruhi perilaku individu. Proses kognitif bertujuan untuk menjelaskan bagaimana informasi eksternal yang diberi pemaknaan menjadi sebuah pemikiran dan penilaian. Sebuah pemikiran adalah hasil dari proses kognitif atau sebagai respon yang berasal dari pengalaman masa lalu dan membentuk penolakan atau penerimaan dari pesan yang diterima.

Terkait dengan penulisan ini, PHW dan HIM merupakan informasi ekternal yang diterima oleh individu yang kemudian akan diolah berdasarkan pengalaman dan pengetahuannya. Kemudian akan membentuk sikap negatif atau positif terhadap pesan tersebut. Sikap yang terbentuk selanjutnya akan mempengaruhi minat si perokok untuk memutuskan akan berhenti merokok atau tidak.

\section{Fear Appeals dan Fear Arousal}

Fear Appeals didefinisikan sebagai suatu pesan komunikasi yang berusaha untuk membangkitkan rasa takut yang digunakan sebagai tindakan untuk melindungi diri sendiri (Rogers, 1975). Dalam hal ini, fear appeal merupakan salah satu komunikasi persuasif yang mencoba untuk membangkitkan rasa takut guna meningkatkan motivasi pencegahan dan tindakan perlindungan diri dari bahaya merokok. Dalam tulisan ini, gambar grafis pada kemasan rokok berfungsi untuk memperingatkan konsumen dari konsekuensi negatif yang akan terjadi pada kesehatan sebagai akibat dari merokok, dan pesan peringatan kesehatan ini dapat disebut 
sebagai sebuah pesan untuk menimbulkan rasa takut (seruan rasa takut).

Pesan fear appeal ini untuk mengaktifkan salah satu dari dua proses penerimaan pesan, baik kontrol terhadap suatu bahaya ataupun respon kontrol terhadap rasa takut. Secara teoritis, fear appeal menguraikan tentang dua tipe informasi. Pertama adalah suatu tindakan sebagai upaya untuk membangkitkan rasa takut yakni dengan memperlihatkan gambar peringatan yang berisi suatu ancaman kesehatan (misalnya, "kanker paru-paru") terhadap para perokok atau pihakpihak yang beresiko tinggi atau yang dianggap rentan terkena hal tersebut (ancaman tersebut). Bentuk ancaman tersebut misalnya, "merokok menyebabkan Anda terkena resiko kanker paruparu" ; "kanker paru-paru adalah penyakit yang mematikan". Kedua adalah suatu tindakan sebagai upaya untuk menghindari ancaman yakni dengan melakukan aksi perlindungan terhadap kesehatan yang baik, misalnya berbentuk aksi efektif yang dapat menetralisir suatu ancaman misalnya, "berhenti merokok dapat membantu Anda dalam mencegah kanker paru-paru". Selain itu, perokok juga harus diyakinkan bahwa tindakan tersebut sangatlah mudah untuk dilakukan yakni dengan cara menginformasikan kepada perokok melalui iklan seperti "kelompok berhenti merokok sudah terdapat dimana-mana, bebas biaya, dan sangat mudah untuk bergabung ke dalamnya" (Witte, Meyer, \& Martell, 2001).

Sementara itu fear arousal didefinisikan sebagai keadaan emosional seseorang yang tidak menyenangkan yang dipicu oleh adanya sebuah persepsi akan suatu ancaman. Hal ini diasumsikan seperti keadaan emosional yang mana melibatkan psikologis seseorang seperti respon kognitif, afektif, dan perilaku dalam mengurangi atau menghapuskan rasa takut di dalam dirinya (Rogers \& Deckner, 1975).

Uraian mengenai fear appeal dan fear arousal di atas jika dihubungkan dengan tulisan ini, maka logika yang terjadi adalah ketika para perokok melihat gambar peringatan kesehatan yang terdapat pada kemasan rokok tersebut bisa jadi menimbulkan rasa takut, yang kemudian mempengaruhi kognisi, afektif, hingga perilaku perokok tersebut yakni dari yang semula perokok berat menjadi perokok kadang-kadang bahkan kemudian menimbulkan keinginan atau minat untuk berhenti merokok.

\section{PENUTUP}

\section{SIMPULAN}

Dalam peringatan kesehatan yang berupa PHW dan HIM dalam kemasan rokok berfungsi untuk memperingatkan konsumen / perokok dari konsekuensi negatif pada kesehatan sebagai akibat dari merokok, dan khususnya PHW berfungsi juga sebagai sebuah pesan untuk menimbulkan rasa takut (proses fear appeal). Proses fear appeal inilah yang memunculkan rasa takut pada para perokok yang kemudian mereka akan melakukan sebuah tindakan untuk melindungi diri mereka sendiri. Hal ini dikarenakan pada proses ini nantinya para perokok tersebut akan lebih mengingat isi pesan yang terdapat dalam kemasan rokok, lalu memunculkan kontrol diri atas resiko negatif yang diakibatkan oleh merokok dan memunculkan rasa khawatir atau cemas dalam diri mereka terhadap konsekuensi negatif tersebut, sehingga menyebabkan mereka memiliki persepsi dan niat atau minat untuk berhenti merokok.

Kebijakan atas PHW dan HIM adalah salah satu upaya untuk meningkatkan kesadaran dan minat atau niat berhenti merokok para perokok, karena di dalamnya terdapat hal-hal yang dapat membangkitkan rasa takut (yang menggambarkan suatu konsekuensi negatif dari merokok), yang mana menimbulkan respon kognitifpara perokok untuk memunculkan sebuah kontrol diri untuk tidak merokok lagi atau untuk berhenti merokok. Oleh karena itu kemasan 
rokok saat ini (perpaduan PHW dan HIM) dinilai lebih dapat merebut perhatian calon perokok daripada kemasan rokok yang terdahulu yang hanya berisi peringatan berupa teks saja.

\section{SARAN}

Karena peringatan kesehatan merupakan salah satu alat untuk menekan minat berhenti merokok, maka bagi pemerintah khususnya kementerian kesehatan untuk lebih mempergunakan Pictorial Health Warning daripada Health Information Message dalam kemasanan rokok, karena Pictorial Health Warning dinilai lebih efektif untuk mempengaruhi minat berhenti merokok.

\section{DAFTAR PUSTAKA}

\section{Jurnal dan Artikel}

Argo, J.J., \& Main, K. J. (2004). Meta-analysis of the effectiveness of warning labels. Journal of Public Policy \& Marketing, 23(2), 193-208.

Badan Penulisan dan Pengembangan Kesehatan 2013. Riset Kesehatan Dasar. Jakarta: Kementerian Kesehatan RI.

Belch, George E., Belch, Michael A. (2001). Advertising and Promotion Perspective. KOTA: McGraw-Hill Irwin

Global Health Case Competition. (2014). Developing Tobacco Strategis for the North Sumatra Province Indonesia. Birmingham: Sparkman Center for Global Health.

Hammond, D. D., Fong, G. T., McDonald, P. W., Cameron, R. R., \& Brown, K. S. (2003). Impact of the graphic Canadian warning labels on adult smoking behavior. Tobacco Control, 12(4), 391-395.

Hammond, David. 2011. Health Warning Messages On Tobacco Products: A Review. Tob Control. (2011); 20 (1): 327-337.

Infodatin, Pusat Data dan Informasi Kementerian Kesehatan RI, Mei 2014.

Kees, J., Burton, S., Andrews, J. C., \& Kozup, J. (2010). Understanding how graphic pictorial warnings work on cigarette packaging. Journal of Public Policy and Marketing, 29(2), 265-276.

McGuire, W. J. (1989). The structure of individual attitudes and attitude systems. In A. R. Pratkanis, S. J. Breckler, A. G. Greenwald, A. R. Pratkanis, S. J. Breckler, \& A. G. Greenwald (Eds.), Attitude structure and function (pp. 37-69). Hillsdale, NJ, England: Lawrence Erlbaum Associates, Inc.

Petty, R. E., \& Cacioppo, J. T. (1986). Communication and persuasion: Central and peripheral routes to attitude change. New York: Springer-Verlag. 
Rogers, R. W., \& Deckner, C. W. 1975. Effects of Fear Appeals and Physiological Arousal Upon Emotion, Attitudes, And Cigarette Smoking. Journal of Personality and SocialPsychology , 32, 222-230.

Petty, R. E., \& Cacioppo, J. T. (1986). Communication and persuasion: Central and peripheralroutes to attitude change. New York: Springer-Verlag.

Rencana Strategis Kementerian Kesehatan Tahun 2015-2019. 2015.

Robinson, T., \& Killen, J. (1997). Do cigarette warning labels reduce smoking? Paradoxical effects among adolescents. Archives of Pediatrics \& Adolescent Medicine, 151(3), 267-272.

Rogers, R. W. (1975). A protection motivation theory of fear appeals and attitude change. Journal of Psychology: Interdisciplinary and Applied, 91(1), 93-114.

Tallah, Heba, Mohammed. (2013). The Efficacy of Viewing Health Warnings on Shisha Smoking among Shisha Smokers. Canada.

The ASEAN Tobacco Control Atlas Second Edition, September 2014.

Witte, K., Meyer, G., \& Martell, D. (2001). Effective health riskmessages: A step-by-step guide. Thousand Oaks, CA: Sage Publications.

Witte, K., \& Allen, M. (2000). A meta-analysis of fear appeals: Implications for effective public health campaigns. Health Education and Behavior, 27, 591-615.

Van Schie, E. C. M., Martijn, C., \& van der Pligt, J. (1994). Evaluative language, cognitive effort, and attitude change. European Journal of Social Psychology, 8, 335-348.

\section{Skripsi}

Dieterich, Sara E. (2012). THESIS : "Graphic Cigarette Package Warning Labels : Investigating The Effectiveness of Graphic Images Among New And Occasional Smokers ”. Fort Collins, Colorado : Colorado State University.

\section{Peraturan Pemerintah}

Menteri Kesehatan. 2013. Peraturan Menteri Kesehatan No. 40 Tahun 2013 Tentang Peta Jalan Pengendalian Dampak Konsumsi Rokok Bagi Kesehatan. Jakarta : Menteri Kesehatan.

Peraturan Menteri Kesehatan Republik Indonesia Nomor 28 Tahun 2013 Tentang Pencantuman Peringatan Kesehatan dan Informasi Kesehatan Pada Kemasan Produk Tembakau.

Peraturan Pemerintah Republik Indonesia Nomor 109 Tahun 2012 Tentang Pengamanan Bahan yang Mengandung Zat Adiktif Berupa Produk Tembakau Bagi Kesehatan. 


\section{Internet}

www.depkes.go.id/article/view/15060900001/rokok-illegal-merugikan-bangsa-dan-negara.html. Diakses pada tanggal 13 September 2016.

www.health.kompas.com/read/2015/06/03/110000223/Jumlah.Perokok.Indonesia.10.Kali.Lipat. Penduduk.Singapura. Diakses pada tanggal 13 September 2016.

www.indonesiatobacco.com/2014/09/mencegah-perokok-pemula-dengan-phw.html. Diakses pada tanggal 13 September 2016.

www.merriam-webster.com/dictionary/graphic. Diakses pada tanggal13 September 2016.

www.republika.co.id/berita/gaya-hidup/info-sehat/15/09/11/nuh20i359-who-rokok-pembunuh -enamjuta-orang-per-tahun. Diakses pada tanggal 13 September 2016.

www.republika.co.id/berita/gaya-hidup/info-sehat/15/09/11/nuh1xx359-who-rokok-penyebab-utamakematian. Diakses pada tanggal 13 September 2016. 